\title{
7
}

\section{International Implications}

The opening chapter drew attention to international concepts and debates in social protection, with a view to highlighting the implications for the relationship between employment relations and social policy. The subsequent five chapters presented a comparative-historical case study of that relationship in the context of two countries since 1890. It is now apt, here in the final chapter, to provide a summary of the main findings, and more importantly to re-connect with the wider international applicability of the case study. The discussion thus draws implications from the Australian and New Zealand analysis for methodology in comparative policy analysis, and for social protection in and for other countries.

\section{Social Protection in the Long Term}

Before the end of World War II and just a few short years before the inauguration of the so-called golden age of the welfare state, economic anthropologist Karl Polanyi (1944) showed that social protection was a necessary and permanent architectural feature of capitalism. Indeed it was indispensable if the working classes were to be adequately shielded from the 
worst effects of the market, primarily through 'protective legislation, restrictive associations, and other instruments of intervention'. Importantly, social protection also served the interests of the 'landed classes', who generally supported the processes of 'productive organization' by providing regulatory cover from the effects of markets that could not re-produce themselves (Polanyi 1944: 132). The social policy research community has implicitly, though rarely explicitly, recognised this. As identified in Chapter 1, using a diversity of language, a limited number of social policy scholars have made clear that the welfare state was indispensable in protecting vulnerable individuals from the freely functioning market. It was necessary to establish a 'welfare economy' (Rein 1981) and a 'welfare society' (Rein and Rainwater 1986a). This implied strongly that social policy analysis should go above and beyond the welfare state narrowly defined.

In common with earlier social reformers from the late nineteenth and early twentieth centuries (Hobhouse 1911, 1922; Hobson 1901; Rathbone 1924; Webb 1919), social policy scholars began in the 1980s, through the work of comparativists (Castles and Mitchell 1992, 1993; Esping-Andersen 1990; Lewis 1992) and feminists (Land 1971; Pascall 1986; Williams 1989; Wilson 1977), to see the need to incorporate the worlds of work and employment into discussions of state-provided welfare. Indeed, as Chapter 1 showed, it is arguable that this intellectual movement had started earlier, having been born in the contributions of specialists in post-war welfare state analysis. Titmuss (1958) and Marshall (1963) were prime among them. Scholarship on the 'rediscovery of poverty' (Abel-Smith and Townsend 1965; Townsend 1954, 1962, 1979) also made a major contribution, principally by demonstrating that being in paid work was no guarantee of being out of poverty.

Equally, an intellectual conundrum was identified. How could social policy analysis address the evolution of workers' conditions faced in employment if it was not adequately reflecting on changes over time in the employment relations systems which governed paid work? This is where the historical comparison between Australia and New Zealand came in, and it is what gives the case study driving this book its primary source of value. Francis Castles' (1985) wage-earners' welfare state framework was a vital contribution because it presented the two countries' 
social protection settlement-yes, mainly the one and the same settlement for the two nations - in terms of four interlocking sets of welfare institutions. Two of these related to trade protection and restricted immigration, which together provided employers with relative economic certainty through the absence of 'foreign' competition, to provide customary Australasian employment standards. The other two sets of institutions related to arbitration-based minimum labour standards, and a residual social security system funded through general taxation revenue.

The primary objective of this book has been to examine the relationship between social policy and employment relations, with two considerations in mind. One consideration was the conundrum presented by the relative absence of employment relations in social policy scholarship on the work-welfare relationship. The other was the treatment of employment relations as mainly non-dynamic. The latter was especially problematic in scholarship on Australia and New Zealand, given that Castles' (1985, 1989, 1996) wage-earners' welfare state framework had placed labour standards at the centre of the four-pronged approach to social protection. Employment relations was presented as central, but it was treated as almost unchanging once implemented. Hence the same two countries that Castles analysed formed the basis for the comparative case study of this book.

Chapter 2 covered the period from 1890 to World War I, an era characterised by employment relations being dominant and relatively advanced while social policy was in the early days of its development. Chapter 3 dealt with the period between the two world wars, when the relationship between the two spheres of interest was consolidated, in that social policy had well and truly evolved to the point where it was a social protection partner of equal prominence. Chapter 4 discussed the postWorld War II era up to and including the early 1980s, during which the social policy dimension of the welfare state matured, and the relationship it formed with equal pay and other labour market institutions became more complex. Chapter 5 covered the period from the early 1980s to the mid-1990s, when social protection was restructured as governments and labour movements in both Australia and New Zealand dealt with the increasing pressures wrought by global economic change. Finally, Chapter 6 brought the historical coverage up to date. 
Though each chapter dealt with a distinct era, each applied to its own period the central argument as laid out in Chapter 1. In addition, each chapter sought, through two-country comparative case analysis, to identify and to analyse the institutional and political causes of similarity and difference between Australia and New Zealand. The overriding argument that inspired and drove the analysis was not specific to Australia and New Zealand. It has been argued here that allowing both employment relations and social policy to be dynamic produces a different and more nuanced understanding of similarity and difference in comparative social protection analysis. In the specific case of Australia and New Zealand, the arbitration system was presented as the most important social protection institution, as differences in the New Zealand and Australian versions of it acted to shape most of the other similarities and differences. The literature which informed the comparative analysis in each chapter built from both small-N and large- $\mathrm{N}$ comparative studies that have considered Australia and New Zealand. The principle that informed the utilisation of the literature was that the contributions of each of employment relations and social policy were not only considered but the implications of each for the other were assessed.

Thus Chapter 2 found that Australia and New Zealand were more different during the earliest period of social protection formation than existing accounts have been able to identify. This is mainly because the institutional and political factors which determine the results of the comparison have rarely been considered together in past studies. The primary consideration, though not the only one, was that Australian social protection was formed in a setting dominated by labourism. In New Zealand, by contrast, government policy was mainly driven by a form of liberalism, and social protection was forged partly with the additional interests of the agricultural sector in mind. The very different constitutional settings also played a major role in determining difference, shaping as they did the existence of protective legislation outside of arbitration in New Zealand. Such legislation was all but absent in Australia as it was constitutionally impossible.

The arbitration system was thus formed in different institutional settings from the earliest days. This factor mattered for the rest of time. In Chapter 3, arbitration was found to be more precarious in New Zealand 
than it was in Australia. In New Zealand, arbitration was subject to more serious political attacks from the trade union movement. Compulsory unionism there also played a role, and the vulnerability of arbitration had important implications for the evolutionary story from that point forward. Arbitration was always more securely placed in Australia. In Chapter 4 it was argued that the voluntary nature of union membership in Australia, combined with the absence of direct minimum labour standards legislation at the national level, meant that arbitration continued to be more solidly based. Equal pay in that country, for example, was channeled through the arbitration system. In New Zealand it was subject to direct government legislation.

After both Australia and New Zealand were characterised by incremental improvements in social policy during the inter-war years, there was renewed interest in the post-war period, particularly in New Zealand, where the world's most comprehensive, and the earliest, welfare state was built. As Chapter 4 argues, the relationship between employment relations and social policy was thus made more complex after World War II, and its Australian variant was the less socially generous of the two.

Chapter 5, which covered most of the 1980s and the first half of the 1990 s, found the greatest and most consequential differences between the two national regimes. New Zealand pursued a radical programme of individualisation in both employment relations and social policy. Australia, by contrast pursued an agenda of slower and more politically measured change and oversight, which together represented an integration between employment relations and social policy under a neocorporatist accord signed by the trade union movement and the Labor government. By contrast, National governments in New Zealand effectively decoupled the two, and a regime of severe cuts in protection prevailed. This produced a model which was closer to classical Friedmanite neo-liberal principles.

Finally, Chapter 6 took the comparative evolutionary narrative to the time of writing. It showed clearly that since the first utilisation of a mixedmember-proportional electoral system in the 1996 election, New Zealand has been governed by coalitions which have necessarily been more moderate, regardless of whether they were led by Labour or National. For its part, Australia has been moving closer to where New Zealand was in the 
1980 s and 1990s, and the two countries are now closer than perhaps they have ever been in the long history to meeting in the middle. Both have arrived at similar situations in relation to arbitration, and both are now characterised by relatively integrated social protection arrangements in general. Integration now, however-as in the 1980s and 1990s in Australia-should not be taken to mean superior social protection. Under the Ardern-led Labour government, New Zealand currently sees a slightly less integrated relationship than does Australia, but it offers somewhat better treatment for workers and for the beneficiaries of the welfare state. The prospects for social protection in New Zealand are brighter than they are in Australia, where a conservative government is continuing to increase the harshness of welfare conditionality, to politicise beneficiaries, and to signal more anti-unionism and further decentralisation in employment relations.

\section{Methodology}

The book has achieved its objectives by applying the methodology of historical-institutionalist approach to comparative social science. Historical institutionalism is based on the premise that institutions structure strategic and political decision-making and preference-formation (Steinmo et al. 1992). But institutions do not act alone. They interact in and with the political realm, and with markets and societal interests over time. Historical institutionalism is particularly suited to understanding the relationship between politics and meso-level institutions, of which welfare states and employment relations systems are typical examples (Ramia and Wailes 2006; Wailes et al. 2003). The most compelling reason for adopting this approach is that the analysis is needed to understand institutions-welfare, employment relations and social protection - simultaneously and over a long period of time. As Mahoney and Thelen (2010: 2) make clear, historical institutionalism facilitates long-haul histories because it is especially useful for revealing 'gradual or piecemeal changes', the significance of which is only revealed in aggregate and in the long term. The significance of change is only fully realised, as some say, in the 'fullness of time'. 
Institutionalist methodology tends to be dominant in comparative social protection research. Employment relations scholars are more explicit in their adherence to it than are their social policy counterparts (Hyman 2001; Ramia and Wailes 2006; Wailes et al. 2003). After all, as argued throughout the book, comparativists are like those analysing the national level, in that both groups of scholars are largely split between the two fields. Regardless of who admits to using which methodology, however, this book makes no claim to representing the only means to conduct comparative-historical research. Indeed, there is a longstanding and influential body of comparative political economy scholarship which, instead of prioritising institutions, focuses attention on 'material interests' in shaping cross-national similarity and difference, particularly in the context of economic change (Gourevitch 1986; Swenson 2002; Schwartz 1994a, b; 2010). The important point here, though, is that for this book the political context is more directly relevant than the economy. The link between the two is not neglected.

There can be little doubt that if this analysis took a different approach, the main findings may have been different. This is not surprising, and debate ought to be welcomed. The social sciences are not precise sciences, and they are necessarily open to debate. Consider also that there are studies which marry interest-based approaches with institutionalism (Garrett and Lange 1996; Hall 1999; Wailes et al. 2003). However, for a longhistorical work such as this, historical institutionalism was more appropriate, given that the literatures on social protection focus more on institutions than on interests.

\section{Implications for Other Countries}

Francis Castles $(1985,1996)$ argued that Australia and New Zealand developed as 'wage-earners' welfare states'. In his view the two regimes consisted of a four-pronged social protection framework, consisting of restricted immigration, trade protection, compulsory arbitration, and mainly residual social policy. As revealed throughout the book, however, issue is taken with Castles' perception of the similarities and differences between the two regimes over time, and the analysis is profoundly critical 
of Castles' treatment of arbitration and employment relations in general. The former problem is a direct result of the latter. To be fair, Castles' (1985) framework represents the original and a prescient contribution to the comparative literature. It was arguably the first post-war book-length work in the field of Anglophone social policy to have seriously incorporated institutions outside of the welfare state. In that sense, it was and remains a major contribution to the broader understanding of the welfare state and indeed of social policy. Castles' legacy has been amply recognised in the literature discussed in the first chapter and throughout.

In a special issue of the Journal of Comparative Policy Analysis on 'social policy by other means', Béland (2019) argues that scholars should 'understand that traditional public welfare state programs are only one of the many potential sources of social protection.' The special issue includes contributions on: migrant workers, working women and labour supply in post-war Europe (Afonso 2019); agricultural and housing policy in Turkey (Dorlach 2019); energy policy in Uruguay (López-Cariboni 2019); and the public/non-state mix of provision in Belgium between 1800 and 1920 (Moeys 2019). On the 'work' side of the work-welfare relationship, Béland (2019: 308) refers specifically to 'economic and labour policies', and Seelkopf and Starke (2019: 220), in their theoretical introduction to the same special issue, refer to 'high levels of labor market regulation with a strong legal norm of a "family wage"'. These formulations stand in contrast to the field of employment relations more broadly defined. The current book sits comfortably within the same body of work and is a kindred spirit with the idea that social policy can be implemented through non-standard or unorthodox institutions, but it adopts a broader definition of employment relations than the social policy literature generally has.

A key part of my central argument is that allowing for greater dynamism in employment relations over the long historical term-in any country and not just the two studied here-can affect perceptions of not just employment relations but social policy and social protection. If Britain were the country of interest, for example, analysis could explore in-depth, and through a continuous evolution, the implications for social policy of what was by tradition a relatively non-interventionist state in employment relations (industrial strikes aside). Though this aspect of 
British labour history is known in the comparative employment relations literature (Bean 1994), its implications for the development of the welfare state are barely explored.

There are other policy arenas which can contribute to the broader understanding of social protection. Harris (2018), for example, unpacks the impact of the decline in mutual aid organisations on the development of the welfare state in the case of Britain in the nineteenth and twentieth centuries. Moeys (2019) achieves something similar in the case of Belgium, though his focus is interplay between public and non-state religious and philanthropic organisations' social provision functions. An important comparison-point to these, based on the current analysis, would be between a country that has a strong tradition of such non-state provision, and a country that does not. Or between two countries that do, but which have other differences that are pertinent to a comparative research design. This would be in line with the Millian justifications for the comparative method (Mill 1882). Implications for contemporary policy and theory can be drawn.

The alternative forms of social provision may shed light on social protection if comparative analysis includes what some have termed 'functional equivalence' (Seelkopf and Starke 2019). This attributes the same protective function in two or more countries, while each provides for it through different institutional means. Castles (1992) himself uses the example of 'sickness days', which Australia traditionally provided through the industrial awards system, but most other countries provided through the welfare state. Based on this book, family policy makes for a fruitful analysis of equivalence. In history, Australia and New Zealand delivered the state's family-based policy aims mainly through the employment relations system, especially through 'family wage' concepts in arbitration. Most other developed countries have relied on the welfare state to deliver for families; which is to say nothing of adequacy in any particular country. An additional or alternative study might consider the interplay between employment relations and social policy in the design and delivery of family-based policies or policy agendas. Naturally, such studies are plentiful, and some have been discussed and cited in previous chapters, though the recommendation here would be for new research to allow for 
changes in employment relations over time; to see if and where such changes may affect social protection patterns or outcomes.

This kind of research would be useful, first of all, in understanding, and second, in addressing the societal, labour market and demographic transformations and challenges which were foregrounded in Chapter 1. It will be recalled that these included: the long-term absence of full employment and the growth of under-employment, particularly in the context of de-industrialisation; the proliferation of the working poor; employers' use of 'zero hours contracts' and so-called gig work; long-term shifts in fertility rates; increases in the proportion of sole-parent households; the increased recognition of mental health conditions, which may make employment more difficult to find or to keep; conflicts between work, employment and family life; the impact on work and employment of new technologies and especially digitisation and artificial intelligence; and the increasing need for care work, and its recognition as work. Each and potentially all of these manifestations of change have given rise to the new class of workers that British economist Guy Standing (2011) calls 'the precariat'; the kind of class whose members find few prospects for economic status improvement. In Standing's view, the precariat is a politically 'dangerous class' because it can rise up further in resisting growing inequality, and it has done so in the 'occupy' movement, for example.

Employment relations research, if it is placed in the context of social protection, is crucial for determining the processes which establish the working conditions and the broader rights of precarious workers. Supplementing such research with the welfare state can help to identify working and wider social conditions together. This is vital, given that the vulnerable subjects of societal transformation are often in and out of employment, or are doing care or other forms of work at home which are not officially recognised. In addition, taking into account workfare may provide more clues on how work and employment interact with social policy to determine the living standards and lifestyles of precariously placed people.

Precarity connects with questions on tax-transfer systems and policy trade-offs, particularly the receipt of in-work social security benefits and tax credits. As will be recalled, the identification of 'fiscal welfare' as a specific category dates back to Richard Titmuss (1956/1976), and in 
more recent times it has been associated with a so-called hidden welfare state. This is the term used by Christopher Howard (1997) in the context of the United States. Titmuss (1956/1976) additional innovation, as problematised in his essay on the 'social division of welfare', was the concept of 'occupational welfare'. That concept referred specifically to benefits gained through participation in the workplace, but also serves as an example of 'private' benefits or sources of welfare, which can include occupational medical and health insurance and pension plans (Béland and Gran 2008; Rein 1981; Rein and Rainwater 1986b). Such private provisions engage the individual beneficiary in the market, through participation as an employee, and often through the commercial (as opposed to the 'social') side of the insurance industry. My reference to 'beneficiary' here is intentional. As Titmuss (1956/1976) argued, occupational welfare is 'welfare' in much the same sense as other forms of welfare, though its sources and its recipients are not the same.

This involvement of the private sector in welfare has its limits, however. Polanyi (1944) had warned in his treatment of the relationship between social protection and 'economic liberalism', of the dangers of the 'self-regulating market'. As pointed out earlier, social protection serves not only workers and vulnerable members of society. It acts in the interests of the capitalist and landed classes by providing a counterweight to unsustainable market forces. The concept of social protection entailed not only welfare measures and minimum labour standards. In Polanyi's framework it included institutions which keep money and land intact for the service of people across society's classes and for the upkeep of the economy.

Translated for the purpose of understanding policy making, social protection prevents over-exploitation within the market, and it is there to demonstrate the limits of the market to governments who should heed its message. In the New Zealand case, as argued in Chapters 5 and 6, the introduction of the Mixed-Member Proportional voting system was the key institution. Its introduction, and the abandonment of the First-Pastthe-Post system, demonstrated the limits of the Bolger governments' political capacity to prioritise market self-regulation at the cost of human welfare. In Australia, that same tipping-point was arguably reached and demonstrated in the failure of the Howard government to stay in office in 
the election of 2007. That election was fought in large measure over WorkChoices and the threat that it represented to workers and trade unions. It will be recalled that the government had control of both chambers of the parliament. The pivotal institution in that case was the Senate, which had over-reached in allowing WorkChoices to pass into legislation.

The main implication of both of these episodes in policy making is that, in the comparative research community, we have more extensive explanations for the retreat of social protection, and fewer explanations for improvements in it, or the in-built limitations upon it. There are exceptions to this; a prominent analysis being Paul Pierson's (1994) Dismantling the Welfare State, which demonstrated the institutional limits that the Reagan Administration and the Thatcher government faced in attempts to retrench welfare in the United Kingdom and the United States respectively.

An important question raised by such limitations, which were observed in the past, is whether some policy agendas in social protection internationally can be sustained in the future. For instance, can the march toward workfare continue or will it face institutional impediments in the longer term? Approaches that come from the 'material interests' standpoint will be important there, because the economic context may be the primary determinant of ongoing feasibility. In addition, though as part of the same line of research, what will be the limits placed upon the melding of the work and employment agendas with social policy developments? What will employment look like in the future, given the technological trends that can be seen today and projected from our time? One possible saving grace could come from more progressive interaction patterns, to be designed by policy makers, between social policy and employment relations. In comparative social protection analysis in Australia and New Zealand, this book has argued that the key institutional interaction has been between arbitration in particular, and social policy. In that sense arbitration has been the lynchpin institution; if indeed there can be a single institution that is of such pivotal importance that other institutions radiate from it or respond to it. Analyses of other countries arguably benefit from a search for institutions with this kind of centrality to wider policy agendas. 


\section{References}

Abel-Smith, B., \& Townsend, P. (1965). The Poor and the Poorest: A New Analysis of the Ministry of Labour's Family Expenditure Surveys of 1953-54 and 1960. London: Bell.

Afonso, A. (2019). Migrant Workers or Working Women? Comparing Labour Supply Policies in Post-War Europe. Journal of Comparative Policy Analysis, 21(3), 251-269.

Bean, R. (1994). Comparative Industrial Relations: An Introduction to Crossnational Perspectives. London: Cengage.

Béland, D. (2019). Varieties of Social Policy by Other Means: Lessons for Comparative Welfare State Research. Journal of Comparative Policy Analysis, 21(3), 306-311.

Béland, D., \& Gran, B. (Eds.). (2008). Public and Private Social Policy: Health and Pension Policies in a New Era. Basingstoke: Palgrave.

Castles, F. G. (1985). The Working Class and Welfare: Reflections on the Political Development of the Welfare State in Australia and New Zealand, 1890-1980. Wellington/Sydney: Allen and Unwin.

Castles, F. G. (1989). Social Protection by Other Means: Australia's Strategy of Coping with External Vulnerability. In F. G. Castles (Ed.), The Comparative History of Public Policy (pp. 16-55). Cambridge: Polity Press.

Castles, F. G. (1992). On Sickness Days and Social Policy. The Australian and New Zealand Journal of Sociology, 28(1), 29-44.

Castles, F. G. (1996). Needs-based Strategies of Social Protection in Australia and New Zealand. In G. Esping-Andersen (Ed.), Welfare States in Transition: National Adaptations in Global Economies (pp. 88-115). London: SAGE Publications.

Castles, F. G., \& Mitchell, D. (1992). Identifying Welfare State Regimes: The Links Between Politics, Instruments and Outcomes. Governance, 5(1), 1-26.

Castles, F. G., \& Mitchell, D. (1993). Worlds of Welfare and Families of Nations. In F. G. Castles (Ed.), Families of Nations: Patterns of Public Policy in Western Democracies (pp. 93-128). Aldershot: Dartmouth.

Dorlach, T. (2019). Retrenchment of Social Policy by Other Means: A Comparison of Agricultural and Housing Policy in Turkey. Journal of Comparative Policy Analysis, 21(3), 270-286.

Esping-Andersen, G. (1990). The Three Worlds of Welfare Capitalism. Cambridge: Polity Press. 
Garrett, G., \& Lange, P. (1996). Internationalisation, Institutions and Political Change. In R. Keohane \& H. Milner (Eds.), Internationalization and Domestic Politics (pp. 48-75). New York: Cambridge University Press.

Gourevitch, P. (1986). Politics in Hard Times: Comparative Responses to International Economic Crises. Ithaca: Cornell University Press.

Hall, P. (1999). The Political Economy of Europe in an Era of Interdependence. In H. Kitschelt, P. Lange, G. Marks, \& J. D. Stephens (Eds.), Continuity and Change in Contemporary Capitalism (pp. 135-163). New York: Cambridge University Press.

Harris, B. F. (2018). Social Policy by Other Means?: Mutual Aid and the Origins of the Modern Welfare State in Britain During the Nineteenth and Twentieth Centuries. Journal of Policy History, 30(2), 202-235.

Hobhouse, L. T. (1911). Liberalism. London: Williams and Norgate.

Hobhouse, L. T. (1922). The Elements of Social Justice. London: Allen and Unwin. Hobson, J. A. (1901). The Social Problem. London: Life and Work.

Howard, C. (1997). The Hidden Welfare State: Tax Expenditures and Social Policy in the United States. Princeton: Princeton University Press.

Hyman, R. (2001). Trade Union Research and Cross-National Comparison. European Journal of Industrial Relations, 7(2), 203-232.

Land, H. (1971). Women, Work and Social Security. Social and Economic Administration, 5(3), 183-192.

Lewis, J. (1992). Gender and the Development of Welfare Regimes. Journal of European Social Policy, 2(3), 159-173.

López-Cariboni, S. (2019). Informal Service Access in Pro-Cyclical Welfare States: A Comparison of Electricity Theft in Slums and Regular Residential Areas of Montevideo. Journal of Comparative Policy Analysis, 21(3), 287-305. Mahoney, J., \& Thelen, K. (2010). A Theory of Gradual Institutional Change. In J. Mahoney \& K. Thelen (Eds.), Explaining Institutional Change: Ambiguity, Agency and Power (pp. 1-37). Cambridge: Cambridge University Press.

Marshall, T. H. (1963). Citizenship and Social Class. In T. H. Marshall (Ed.), Sociology at the Crossroads, And Other Essays. London: Heinemann.

Mill, J. S. (1882). A System of Logic, Ratiocinative and Inductive: Being a Connected View of the Principles of Evidence and the Methods of Scientific Investigation (8th ed.). New York: Harper \& Brothers.

Moeys, H. (2019). Social Policy by Other Means from a Comparative Historical Perspective: Continuity and Change in Nineteenth-Century Belgium (1800-1920). Journal of Comparative Policy Analysis, 21(3), 235-250. 
Pascall, G. (1986). Social Policy: A Feminist Analysis. London: Tavistock Publications.

Pierson, P. (1994). Dismantling the Welfare State? Reagan, Thatcher and the Politics of Retrenchment. Cambridge: Cambridge University Press.

Polanyi, K. (1944). The Great Transformation. New York: Farrar/Rinehart.

Ramia, G., \& Wailes, N. (2006). Putting Wage-Earners into Wage Earners' Welfare States: The Relationship Between Social Policy and Industrial Relations in Australia and New Zealand. Australian Journal of Social Issues, 4(1), 49-68.

Rathbone, E. F. (1924). The Disinherited Family: A Plea for the Endowment of the Family. London: Edward Arnold and Co..

Rein, M. (1981). Private Provision of Welfare. In R. F. Henderson (Ed.), The Welfare Stakes: Strategies for Australian Social Policy (pp. 9-44). Melbourne: Institute of Applied Economic and Social Research.

Rein, M., \& Rainwater, L. (1986a). The Institutions of Social Protection. In M. Rein \& L. Rainwater (Eds.), Public/Private Interplay in Social Protection: A Comparative Study (pp. 25-56). New York: M. E. Sharpe, Inc..

Rein, M., \& Rainwater, L. (Eds.). (1986b). Public/Private Interplay in Social Protection: A Comparative Study. New York: M. E. Sharpe, Inc..

Schwartz, H. (1994a). Public Choice Theory and Public Choices: Bureaucrats and State Reorganization in Australia, Denmark, New Zealand and Sweden. Administration and Society, 26(1), 48-77.

Schwartz, H. (1994b). Small States in Big Trouble: State Reorganisation in Australia, Denmark, New Zealand and Sweden in the 1980's. World Politics, $46(4), 527-555$.

Schwartz, H. (2010). Small States in the Rear-View Mirror: Legitimacy in the Management of Economy and Society. European Political Science, 9, 365-374. Seelkopf, L., \& Starke, P. (2019). Social Policy by Other Means: Theorizing Unconventional Forms of Welfare Production. Journal of Comparative Policy Analysis, 21(3), 219-234.

Standing, G. (2011). The Precariat: The New Dangerous Class. London: Bloomsbury Academic.

Steinmo, S., Thelen, K., \& Longstreth, F. (Eds.). (1992). Structuring Politics: Historical Institutionalism in Comparative Analysis. Cambridge: Cambridge University Press.

Swenson, P. (2002). Capitalists Against Markets: The Making of Labor Markets and Welfare States in the United States and Sweden. Oxford: Oxford University Press. 
Titmuss, R. M. (1956/1976). The Social Division of Welfare: Some Reflections on the Search for Equality. In K. Titmuss (Ed.), Essays on 'The Welfare State' (pp. 34-55). London: Allen and Unwin.

Titmuss, R. M. (1958). The Social Division of Welfare: Some Reflections on the Search for Equity. In R. M. Titmuss (Ed.), Essays on 'The Welfare State' (pp. 34-55). London: Unwin University Books.

Townsend, P. (1954). Measuring Poverty. British Journal of Sociology, 5(2), 130-137.

Townsend, P. (1962). The Meaning of Poverty. British Journal of Sociology, 13(3), 210-227.

Townsend, P. (1979). Poverty in the United Kingdom: A Survey of Household Resources and Standards of Living. Harmondsworth: Penguin Books.

Wailes, N., Ramia, G., \& Lansbury, R. (2003). Interests, Institutions and Industrial Relations. British Journal of Industrial Relations, 41(4), 617-637.

Webb, B. (1919). Report of the War Cabinet Committee on Women in Industry: Minority Report by Mrs Sidney Webb. London: His Majesty's Stationery Office. Williams, F. (1989). Social Policy: A Critical Introduction; Issues of Race, Gender and Class. Cambridge: Polity Press.

Wilson, E. (1977). Women and the Welfare State. London: Tavistock Publications.

Open Access This chapter is licensed under the terms of the Creative Commons Attribution 4.0 International License (http://creativecommons.org/licenses/ by/4.0/), which permits use, sharing, adaptation, distribution and reproduction in any medium or format, as long as you give appropriate credit to the original author(s) and the source, provide a link to the Creative Commons licence and indicate if changes were made.

The images or other third party material in this chapter are included in the chapter's Creative Commons licence, unless indicated otherwise in a credit line to the material. If material is not included in the chapter's Creative Commons licence and your intended use is not permitted by statutory regulation or exceeds the permitted use, you will need to obtain permission directly from the copyright holder.

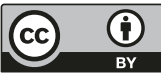

